\title{
Improving the Learning Quality of Math Teachers through the Academic Supervision with Technique of Class Observation
}

\author{
Suparto* \\ Dinas Pendidikan Kabupaten Nganjuk
}

*Coressponding author Suparto

$\bowtie$ suparto.kts@gmail.com

\begin{abstract}
Improving the Learning Quality of Math Teachers through the Academic Supervision with Technique of Class Observation. This study aims to find out directly the problems of mathematics teachers and also provides advice, information, and motivation to improve the quality of teaching and learning process, followed by the relevant training based on the problems found and faced by math teachers. This study is a classroom action research using 2 cycles. The results showed that academic supervision with classroom observation techniques can improve the quality of mathematics teacher learning in SMPN 3 Kertosono Nganjuk academic year 2015/2016.
\end{abstract}

Keywords

learning quality; academic supervision; observation technique

\section{INTRODUCTION}

Referring to the Regulation of the Minister of National Education Number 12, 2007, concerning School/Madrasah Supervisor Standard, it is stated that the supervisor must have the competence of training teachers in choosing and using the strategy/method/technique of learning/guidance that can develop various potential students through subjects in clump relevant subjects in similar schools.

Teacher training is certainly based on the fact of a teacher who is trained, whether it has problems or not. For teachers who have problems with learning, school supervisors need to conduct academic supervision actions. In this case, academic supervision should be done with a clinical supervision approach that is carried out continuously through the pre-observation stage, observation of learning, and post-observation.

Based on the results of preliminary studies at SMPN 3 Kertosono Nganjuk academic year 2015/2016, it found various problems of math teachers in implementing learning. The problems that arise are as follows: math teachers are less in organizing teaching and learning activities or the use of variations of learning methods, classroom management, the use of visual aids, encourage student creativity in solving various problems, arrange learning activities in accordance with methods, subjective and objective, knowing the real positive and negative aspects of the learning process and service to students who experience various barriers to learning.

To overcome various problems in learning, the school supervisors need to conduct follow-up through academic supervision with classroom observation techniques. Academic supervision with classroom observation technique is intended to directly understand the various problems faced by math teachers and also provide advice, input, information, and motivation to the math teachers to improve the quality of teaching and learning process, followed by the relevant training based on the problems found and encountered during the observation process. Academic supervision is a coach training activity by providing technical assistance to teachers in implementing the learning process that aims to improve the professional skills of teachers and improve the quality of learning. Academic supervision with classroom observation techniques in this study is basically a process of observation of learning followed by training to math teachers to improve the situation and learning activities so that students can learn effectively and efficiently.

The purpose of the academic supervision action through classroom observation techniques by the school supervisor to the math teachers are: (1) Collect data objectively, without the background of right or wrong and the correctness of criteria; (2) Determine cooperatively the advantages and disadvantages of the learning 
process based on data obtained in the field; (3) Try to find ways to improve and improve the learning quality, both from teachers and students as the target of learning; (4) Encourage math teachers with advice, suggestion and information to improve performance in learning; and (5) Conduct a training according to the needs of the math teachers based on various findings of the problems faced by the teachers.

\section{METHODS}

This research was conducted at SMP Negeri 3 Kertosono, academic year 2015/2016. The subject of this research is 3 mathematics teachers who have civil servant status (PNS). This study uses classroom action research. Classroom action research (PTK) was chosen as a research method used by the researcher to answer the emerging problems. In addition, classroom action research is a type of research that serves to improve the learning process in several cycles. McNiff \& Whitehead (2002: 15) states that research is centered on the learning process. Carr and Kemmis in McNiff, J. (1991) mention that classroom research is a form of self-inquiry through self-reflection by educational practitioners in social situations to improve the rationality and quality of educational practice performance, understanding of educational practices, and the context in which work practices. This study was conducted by 2 cycles. Each cycle consists of several stages: planning, acting, observing, and reflecting.

In cycle I, the action starts with planning. Planning undertaken such as drafting guidelines and instruments of academic supervision, developing an academic supervisory plan (RKA), developing analysis guidelines and indicators of the success of the outcome of the action. have evaluations and discussion of observation results, follow up or replanning for cycle II, if the results achieved, have not been able to achieve an indicator of success. Then apply the action based on the planning for the cycle I. At the time of implementation of the action, the school supervisor/researcher conducts the observation by using the observation instrument to collect the research data. At the reflection stage, the school supervisor/researcher reiterated the observation of teacher learning. School supervisor/researcher and math teachers evaluate the processes and outcomes of action together, including discussing and discussing the advantages and disadvantages of the results of cycle action 1 . If the processes and outcomes achieved in cycle 1 can achieve the success indicator, then the action is stopped. However, if the results of the action cannot achieve the success indicator, then the replanning for cycle II, which includes the activities of re-planning, repeated action, re-observation, and re-reflection.

Data collection in this research using observation and interview method. The type of observation is the participant observation that is arranged systematically that its implementation using the framework in advance, which arranged based on things to be observed with certain categories. Observation tool used in the form of Check List.

The method of observation validation in this research is done by logical validation, that is, from the beginning of the compilation follow the steps of arranging the correct instrument. Breaking of variables into sub-variables and indicators are needed in making the items of question are done carefully (Arikunto, 2002: 145). While in the interview, the way technique used is the direct and structured interview, means that the researcher compiles a list of questions that must be answered directly by the informant. The instruments used are observation sheet S1, Evaluation Check List (S2) and Activity Check List about teaching and learning process, and structured interview sheet. Scale checklist both S1 and S2 has been designed in such a way based on the concept of research variables that have been broken into indicators that are translated through the questions.

\section{RESULTS AND DISCUSSIONS}

If it is examined from the root (etymology), the supervision comes from English "Supervision" which consists of two words namely "Super" and "Vision". Super means over or above, while vision means seeing or reviewing (Nawawi, 1984). When it is viewed in terms of meaning (semantics) there are some views on the definition of supervision. According to Wiles (in Sutisna, 1983) supervision is an assistance to improve teaching and learning situations. Adam and Dickey (in Sahertian, 2000) define supervision as a planned program to improve teaching. Boardman (in Sahertian, 2000) defines that supervision is an attempt to stimulate, coordinate and guide sustainably the growth of teachers in schools, both individually and collectively, in order to better understand and be more effective in realizing all the teaching functions. Mc. Nerney (in Sahertian, 2000) sees the supervision as a procedure that gives direction and makes a critical assessment of the teaching process. 


\section{Cycle I}

Based on the results of the researcher's observations and notes that were made by math teachers who became the subject of research, it found that the learning activities in cycle I that they have done into the category was not enough, so the action declared as not yet successful. From the results of the researcher's note, there are weaknesses and advantages experienced by the three math teachers during carrying out the learning activities. The weaknesses are: (1) all teachers do not have enough confidence in implementing learning method; (2) there is a fear of mistake in explaining the subject matter; (3) result of observation (C1) learning activity is not maximal; (4) Evaluation Check List (C2) result not maximal; (5) Activity Check List (C2) result of learning activity is not maximal; (6) teaching methods applied by teachers are still conventional; (7) there are less active activities of students and teachers. Meanwhile, the advantages of cycle I action are: (1) all math teachers arrive on time during the course of the research; (2) all math teachers are able to prepare the class well; (3) all math teachers have a complete Lesson Plan; and (4) they have readiness to carry out supervision activities with classroom observation techniques.

The training that was given by the researcher as supervisor in cycle I is in the form of giving positive appreciation to all math teachers in the implementation of learning activities and suggests that teachers remain optimistic and confident to carry out learning activities, and able to fix the weaknesses that occur in cycle I. Supervisor/researcher also convinces and motivates all math teachers that they can find out for themselves all the weaknesses and problems in carrying out learning activities and able to independently overcome all those weaknesses, because they have experience and long teaching hours as a math teachers.

\section{Cycle II}

Based on the results of observations of researcher and records that have been made by teachers of mathematics, found that learning activities in cycle II are already in the satisfactory category, so the action declared successful. The training conducted by the researcher as the school supervisor is: (1) the school supervisor/researcher gives positive appreciation to all math teachers about the implementation of learning activities, and recommends that all teachers remain optimistic and confident and able to carry out the learning activities well, maintains good things and able to fix the weaknesses that may occur; and (2) the school supervisor/researcher assures and motivates all math teachers if they are willing to learn seriously, and often innovates learning, the learning outcomes will be much better and maximum.

Based on the results of observation and evaluation, then it held a mutual agreement between the school supervisor/researcher with all math teachers through discussion to improve the aspects that have not been maximal that occurred in cycle II. There is also an agreement that math teachers are ready to be supervised at any time to improve the quality of their performance and improve their pedagogical and professional competence.

\section{CONCLUSIONS}

Academic supervision with classroom observation techniques can improve the learning quality of math teachers, this can be seen from: (1) the average value of observations (C1) of math teacher learning activities from the initial study, cycle I and cycle II is always increasing. The increase in value is due to the impact of academic supervision actions with classroom observation techniques; (2) the average result of the evaluation checklist (C2) of the math teachers learning activity from the initial study, cycle I and cycle II are always increasing, the increase in value is due to the impact of academic supervision actions with classroom observation techniques; and (3) the average activity checklist (C2) of math teachers learning activities from the initial study, cycle I, and cycle II is always increasing, the increase in value is due to the impact of academic supervision actions with classroom observation techniques.

Based on the results of the conclusions mentioned above, this study suggests: (1) In order to carry out academic supervision by classroom observation techniques on mathematics learning activities, school supervisors should use standardized tools to produce better results; (2) in order that the observation in the classroom can run smoothly based on the objectives, the school supervisors should maintain a harmonious relationship with math teachers or other subject teachers by establishing interpersonal communication, both during the learning process and beyond the learning process, either formal or non-formal; (3) in order to make learning activities run effectively and efficiently, math teachers should develop an easy Lesson Plan to be implemented; and (4) in order to create effective and efficient learning, both from the students and the math teachers, the teachers should apply varied, constructive and innovative teaching methods, and always 
conduct mentoring, motivation and discipline to all students, so that the learning activities run smoothly with satisfactory results.

\section{REFERENCES}

Arikunto, S. 2002. Research Procedure A Practice Approach. Jakarta: Rineka Cipta.

McNiff, J. 1991. Action Research Principles and Practice. Britain: PLC.

McNiff, J. \& Whitehead, J. 2002. Action Research Pronciples and Practice: Second Edition. London: Routledge Falmer.

Minister of National Education Regulation Number 12, 2007 on Maret 28, 2007 about School Supervisory Standards. Jakarta: Departemen Pendidikan Nasional.

Nawawi, H. 1984. Administration of Education. Jakarta: Gunung Agung.

Sahertian, P. A. 2000. Basic Concepts \& Education Supervision Techniques in the Framework of Human Resource Development. Jakarta: Rineka Cipta.

Sutisna, O. 1983. Administration of Education, Theoretical Basis for Professional Practice. Bandung: Angkasa. 